\title{
Bioactive Cyclopentenone Derivatives from Marine Isolates of Fungi
}

\author{
Zhile Feng, Alain S. Leutou, Guohua Yang, Viviane N. Nenkep, Xavier N. Siwe, Hong Dae Choi," \\ Jung Sook Kang, ${ }^{*}$ and Byeng Wha Son ${ }^{*}$ \\ Department of Chemistry Puhyong Kational Lniversity, Busan 608-737, Korea. 'E-mail: sonbw Gipknuackr \\ ${ }^{\dagger}$ Department of Chemistrv, Dongeui Chiversity, Busan 614-714, Korea \\ 'College of Dentistrv. Pusan National Chiversin. Yangsan. Gveongnam 626-770. Korea \\ Received April 4, 2009, Accepted August 28, 2009
}

\begin{abstract}
As part of an effort to discover bioactive natural products from marine sources, we investigated the bioactive secondary metabolites from two marine isolates of the fungi, Trichodema viride and Rhizopus stolonifer. Three cyclopentenones, myrothenones A $(\mathbf{1})$ and B $(2)$ and trichodenone A $(3)$, were isolated from $T$. viride and two cyclopentenones, 2-bromomyrothenone $\mathrm{B}(\mathbf{4})$ and botrytinone $(\mathbf{5})$, were isolated from $R$. stolonifer. The molecular structures and absolute stereochemistries of the cyclopentenones were determined from chemical and physicochemical evidence, including quantum chemistry calculations, X-ray analysis, and the circular dichroism (CD) exciton chirality method. Myrothenone A (1) displays tyrosinase inhibitory activity, with an IC $\varsigma_{0}$ value of $6.6 \mu \mathrm{M}$, and is therefore nore active than the positive control, kojic acid.
\end{abstract}

Key Words: Trichoderma viride. Rhizopus stolonifer. Cyclopentenone, Myrothenone, Botrytinone

\section{Introduction}

Cyclopentenone is ubiquitous among natural and non-natural organic molecules. and its derivatives play important roles in chemistry and biology because the $\alpha . \beta$-lunsaturated carbonyl group of cyclopentenone is an electrophilic center susceptible to addition reactions with mucleophiles. Simple cryclopentenones are not only reactive functional groups in biological sy stem, ${ }^{1}$ but also important intermediates in the synthesis of complex targets. ${ }^{2}$ For example. cyclopentenone prostaglandins A2. B2. $\mathrm{C} 2$. and $\mathrm{J} 2$ are naturally occurring representative biological cyclopentenone derivatives. ${ }^{1}$ and a cyclopentenone derivative. methyl didehydrojasmonate. with a cyclopentenone pharmacophore introduced into the molecule exhibits 29 -fold greater antiproliferative activity against cancer cells. ${ }^{3}$ Many bioactive cyclopentenone derivatives have been isolated from natural sources (e.g. marine- and terrestrial-derived fungi $i^{4-16}$ liverwort, ${ }^{17}$ and plants ${ }^{\dagger}$ ) and exhibit diverse biological activities. including antimitotic. ${ }^{+}$antiinflammatory. cyclooxy'genase 2 (COX-2) inhibitory. ${ }^{18}$ cytotoxic. ${ }^{+6.19}$ NF-kB inhibitory. ${ }^{10.11}$ antimicrobial. ${ }^{9.12-15.17}$ antipigment, ${ }^{12.14}$ and plant-growth-regulatory activities. ${ }^{12-14.17}$ The cyclopentenones have several asy mmetric centers in the molecule. Therefore. we are interested in their chemical and biological aspect as well as their structureactivity relationships (SARs). As part of an effort to discover biologically active natural products. including cyclopentenones.

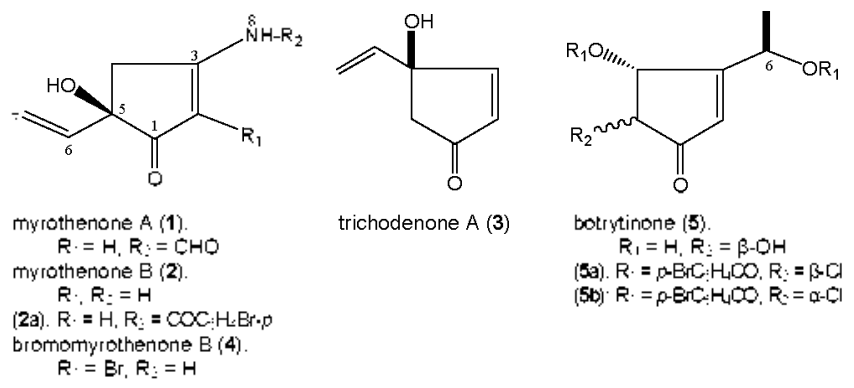

from marine sources, we investigated the bioactive secondary metabolites of two marine isolates of the fungi. $T$. viride and R. stolonifer. and isolated three cyclopentenones. ${ }^{2(1}$ my rothenones A (1) and B (2) and trichodenone A (3) from $T$. viride, isolated from the edible marine red alga. Gracilaria vernicosa. and two cyclopentenones. ${ }^{21}$ 2-bromomyrothenone $\mathrm{B}(t)$ and botrytinone (5). from $R$. stolonifer, isolated from the edible marine brown alga. Sargassum homeri.

\section{Experimentals}

Gene1al. Optical rotation was determined on a Perkin Elmer model 341 polarimeter. CD spectra were taken on a JASCO J-715 spectropolarimeter. UV/Visible spectra were measured on a Hitachi U-200l UV/Vis spectrometer. IR spectra were recorded on a Bruker FT-IR model IFS- 88 spectrometer. ${ }^{1} \mathrm{H}$ $(400 \mathrm{MHz})$ and ${ }^{13} \mathrm{C}$ NMR $(100 \mathrm{MHz})$ spectra were obtained on a JEOL JNM-ECP 400 NMR spectrometer, using TMS or solvent peaks as reference standard. MS spectra were obtained on a JEOL JMS-700 spectrometer. Single-crystal X-ray measurements were performed on a Bruker SMART CCD diffractometer.

Fungal isolation and culture. Two fungal strains. MFA 811 and MFB063. were isolated from the surface of the edible marine red alga Gracilaria verrucosa and from the surface of the edible marine brown alga Sargassum homeri. collected at Yokji Island of Gyeongnam. Korea in 2008. and identified as $T$. viride and $R$. stolonifer based on $18 \mathrm{~S}$ rRNA analy ses (SolGent Co.. Ltd. Daejeon. Korea), identities of each $100 \%$. respectively. Two voucher specimens are deposited at Pukyong National University with the code MFA811 and MFB063. Two fungal strains were cultured $(1 \mathrm{~L} \times 20)$ for three weeks (static) at $29^{\circ} \mathrm{C}$ in SWS medium consisted of soytone $(0.1 \%)$, soluble starch $(1.0 \%)$, and seawater $(100 \%)$.

Extraction and isolation. The cultured media of $T$. viride and $R$. stolonifer were filtered through cheesecloth to give 
mycelium and broth. The filtered broths were extracted with EtOAc to afford broth extracts of T. viride ( $1.2 \mathrm{~g}$ ) and of $R$. stolonifer $(1.0 \mathrm{~g})$. respectively. The broth extract of $T$. wiride was purified by assay-guided fractionation using repeated silica gel flash chromatography ( $n$-hexane in ethyl acetate) and HPLC (ODS-A. MeOH- $\mathrm{H}_{2} \mathrm{O}=5: 1$ ) to yield three cyclopentenones. my rothenones $A(1)(9.5 \mathrm{mg})$ and $B(2)(10.4 \mathrm{mg})$ and trichodenone $\mathrm{A}(3)(4.6 \mathrm{mg})$. While. the broth extract of $R$. stolonifer was subjected to silica gel flash chromatography. Elution was performed with $n$-hexane-EtOAc (stepwise. 0 $100 \%$ EtOAc) to yield four fractions. Fractions 2 and 3 on medium pressure liquid chromatography (MPLC) (ODS) by elution with $\mathrm{H}_{2} \mathrm{O}-\mathrm{MeOH}$ (from $1: 1$ to $1: 5$ ) afforded crude compounds 4 and 5. which were further purified by HPLC (YMC. ODS-A) utilizing a $30 \mathrm{~min}$ gradient program of $50 \%$ to $100 \% \mathrm{MeOH}$ in $\mathrm{H}_{2} \mathrm{O}$ to furnish $4(9.3 \mathrm{mg})$ and $5(6.6 \mathrm{mg})$. respectively:

My rothenone A (1): A colorless oil; $[\alpha]_{D}^{30}=+61^{\circ}$ (c 0.6 . $\mathrm{MeOH}): \operatorname{IR}(\mathrm{KBr}) 3419.3240 .1683 .1603 .1554 .1524,1+10$. 1318, 1189. 1093. $1005 \mathrm{~cm}^{-1}$; UV (MeOH) $203 \mathrm{~mm}(\log \varepsilon 3.7)$. 272 (4.2); LR EI MS $m / z 167$ [M] $^{+}$(rel. int. 34). 139 [M-CO] $^{+}$ (50). $122[\mathrm{M}-\mathrm{CO}-\mathrm{OH}]^{-}(10) .111(43) .94(54) .84(43) .68(72)$. 55 (100); HR FAB MS $m / z 190.0482[\mathrm{M}+\mathrm{Na}]^{+}$(calcd for $\mathrm{C}_{8} \mathrm{H}_{9}$ $\mathrm{NO}_{3} \mathrm{Na} .190 .0480$ ): See Table 1 for NMR spectral data.

My rothenone B (2): A colorless oil; $[\alpha]_{D}^{30}=+35^{\circ}$ (c 0.6 . $\mathrm{MeOH}):$ IR (KBr) $3390,3210,1630,1552,1+14,1271$. I221. 1123. $1072 \mathrm{~cm}^{-1}$ : UV (MeOH) $203 \mathrm{~nm}(\log \varepsilon 3.7) .268(4.0)$ : $\mathrm{CD}(\mathrm{MeOH}) \lambda_{\max }(\Delta \varepsilon) 281(+0.4) .259(-0.1)$ num; LR EI MS $m / 2139[\mathrm{M}]^{+}$(rel. int. 87), $122[\mathrm{M}-\mathrm{OH}]^{+}(13), 110(84), 94$ (33). $83(83) .67(32) .55$ (100); HR FAB MS $m / z 140.0710$ $\left[\mathrm{M}+\mathrm{H}^{+}{ }^{+}\right.$(calcd for $\mathrm{C}_{-} \mathrm{H}_{10} \mathrm{NO}_{2}, 140.0712$ ): See Table 1 for NMR spectral data.

Trichodenone $\mathbf{A}$ (3): was obtained as a colorless oil. and showed spectral data virtually identical to those reported in the literature. 5,6

Bromomy rothenone B (4): A colorless oil: $[\alpha]_{\mathrm{D}}^{\hat{j}}+6 \mathrm{l}(\mathrm{c} 0.9$. $\mathrm{MeOH}) ; \mathrm{CD}(\mathrm{MeOH}) \lambda_{\max }(\mathrm{d}) 289(+2.9) .265(-1.4)$ num: UV $(\mathrm{MeOH}) \partial_{\text {thax }}(\log \varepsilon) 210$ (3.7). $277(+.2) \mathrm{mm}$ : IR $(\mathrm{KBr}) \hat{\partial}_{\max }$ $3321.3188 .1630 .1559 .1423 .1262 .102+\mathrm{cm}^{-1}:{ }^{1} \mathrm{H}$ and ${ }^{13} \mathrm{C}$ NMR. see Table l: EIMS $m z 219$ [M] $^{-}(45) .217\left[\mathrm{M}^{+}(45)\right.$. $138[\mathrm{M}-\mathrm{Br}]^{-}(70), 110$ [M-Br-CO] $^{-}(45) .82(40) .68(41) .55$ (100): HREIMS $m / z 218.9725$ (calcd for $\mathrm{C}: \mathrm{H}_{8}{ }^{81} \mathrm{BrNO}$. 218.9718 ). 216.9721 (calcd for $\mathrm{C}_{7} \mathrm{H}_{8}{ }^{7} \mathrm{BrNO}_{3} .216 .9738$ ): See Table 1 for NMR spectral data.

Botrytinone (5): A colorless oil; $[\alpha]_{\mathrm{D}}^{3(1}-5.3$ (c 1.3, MeOH): $\mathrm{CD}(\mathrm{MeOH}) \hat{\lambda}_{\text {max }}(j \varepsilon) 322(+2.5) .228(-12.7) \mathrm{nm}$. UV $(\mathrm{MeOH})$ $\lambda_{\max }(\log \varepsilon) 225(3.8) \mathrm{nm} ; \mathrm{IR}$ (neat) $\lambda_{\max } 3335.1716 .1616$. $1265.1160 .1075 \mathrm{~cm}^{-1}:{ }^{1} \mathrm{H}$ and ${ }^{13} \mathrm{C}$ NMR, see Table I: EIMS $m / z 158\left[\mathrm{M}^{-}\right.$(3). $141[\mathrm{M}-\mathrm{OH}]^{-}$(100). $123(50) .115$ (15). 107 (23). 95 (95). $79(25) .67(62) .55$ (59): HREIMS $m / z 158.0607$ (calcd for $\mathrm{C}_{-} \mathrm{H}_{10} \mathrm{O}_{4}, 158.0579$ ): See Table I for NMR spectral data.

Synthesis of $\mathrm{N}$-( $p$-bromobenzoyl)myrothenone B (2a). $p$-Bromobenzoyl chloride $(0.3 \mathrm{~mL})(0.2 \mathrm{mmol})$ was added to a solution of myrothenone $\mathrm{B}(2)(20 \mathrm{mg})(0.5 \mathrm{mmol})$ in pyridine at $0{ }^{\circ} \mathrm{C}$ under $\mathrm{N}_{2}$ atmosphere, then the mixture was stimed for 12 hours at $60^{\circ} \mathrm{C}$. The reaction mixture was then poured into water and extracted with EtOAc. The EtOAc extract was washed with brine, then dried over $\mathrm{MgSO}_{4}$. Removal of the solvent under reduced pressure from the EtOAc extract gave a product. which was purified by column chromatography (nhexane-EtOAC $=20: 1$ ) to furnish $p$-bromobenzoate derivative (2a. $18 \mathrm{mg}$ ). A colorless tetragonal prism of 2 a was obtained by recrystallization from $n$-hexane and ethyl acetate.

The crystallographic data $2 \mathrm{a}, \mathrm{C}_{1} \mathrm{H}_{12} \mathrm{BrNO}_{3}, \mathrm{Aw}=322.16$. $T=298(2) \mathrm{K} . \lambda=0.71069$ A. monoclinic, $P 22_{1} . a=5.6300$ $(10), b=5.685$ (3). $c=20.715$ (3) A. $\beta=94.850(10)^{\circ} . r^{\circ}=$ 660.6 (2) $\AA^{3}, Z=2$. d dalcd $=1.619 \mathrm{Mg} \mathrm{m}^{-3}, F(000)=324$. The final $R_{1}$ and $w R_{2}$ values with 3375 Friedel pair reflections $([I>2 \sigma(I)])$ were 0.0502 and 0.0541 , respectively. An absolute structure parameter. $\chi=-0.02$ (1). Crystallographic data have been deposited with the Cambridge Crystallographic Data Center (deposit No. CCDC 256884).

Synthesis of mynothenone $\mathbf{A}$ (1). Formic acid $(0.5 \mathrm{~mL})$ ( $12.7 \mathrm{mmol}$ ) and DCC (5 mg) was added to a solution of nyy rothenone $\mathrm{B}(2)(10 \mathrm{mg})(0.5 \mathrm{mmol})$ in pyridine at $0{ }^{\circ} \mathrm{C}$ under $\mathrm{N}_{2}$ atmosphere, then the mixture was stirred for 3 hours. Work-up of the reaction mixture as described above for $p$-bromobenzoylation yielded a product, which was purified by column chromatography (n-hexane-EtOAc $=20: 1$ ) to furnish nyy rothenone $A(8 \mathrm{mg})$. Synthetic conpound was shown to be identical with my rothenone A(1) by TLC. $[\alpha]_{D},{ }^{1} \mathrm{H}-\mathrm{NMR}$ and ${ }^{12} \mathrm{C}-\mathrm{NMR}$.

p-Bromobenzoylation of botrytinone (5). p-Bromobenzoyl chloride $(0.3 \mathrm{~mL})$ was added to a solution of botytinone (5) (10 $\mathrm{mg})(0.06 \mathrm{mmol})$ in pyridine $(0.5 \mathrm{~mL})$ under $\mathrm{N}_{2}$ atmosphere, then the mixture was stirred at r.t. for 1 hour. Work-up of the reaction mixture as described above for $p$-bromobenzoylation yielded products. which were purified by column chromatography ( $n$-hexane-EtOAc $=10: 1$ ) to furnish $p$-bromobenzoate derivatives $\mathbf{5 a}(7 \mathrm{mg}$ ) and $\mathbf{5} \mathbf{b}(2 \mathrm{mg})$.

p-Bromobenzoate delivative (5a). Colorless tetragonal prisims ( $n$-hexane and acetone); CD (MeOH) $\lambda_{\text {miki }}(J \varepsilon) 243(-39.9)$, $225(-8.2) .215(-16.7) .200(+36.7) \mathrm{nm}: \mathrm{UV}(\mathrm{MeOH}) \lambda_{\max }$ (log e) $304(5.8), 283$ (sh) (6.2). 272 (6.4) $\mathrm{mm} ;{ }^{l} \mathrm{H}$ NMR (DMSO- $\left.d_{6 .}+400 \mathrm{MHz}\right) \delta 6.73$ (1H. s. H-2), 6.27 (1H. d. $J=2.5$ Hz. H-4). 5.13 (lH, d, $J=2.5 \mathrm{~Hz}, \mathrm{H}-5) .5 .93$ (lH, q. $J=7.0$ $\mathrm{Hz} . \mathrm{H}-6), 1.57\left(3 \mathrm{H}, \mathrm{d} . J=7.0 \mathrm{~Hz} . \mathrm{H}_{3}-7\right) .7 .69 .7 .75,7.84 .7 .91$ (each $2 \mathrm{H}$, d, $J=8.6 \mathrm{~Hz}, p-\mathrm{BrC}_{6} H_{4} \mathrm{COO} \times 2$ ).

p-Bromobenzoate derivative (5b). A amorphous solid ( $n$ hexane and acetone): $\left.\mathrm{CD}(\mathrm{MeOH}) \mathrm{h}_{\max }(\rfloor \varepsilon\right) 245(-1.07), 224$ $(-0.05) .216(-0.21), 200(+0.91)$ lun: UV $(\mathrm{MeOH}) \lambda_{\max }(\log \varepsilon)$ 298 (6.3). 283 (sh) (6.4). 273 (6.5) $\mathrm{lm} ;{ }^{1} \mathrm{H}$ NMR (DMSO- $d_{6}$. $400 \mathrm{MHz}) \delta 6.71$ (lH. s. H-2). 6.34 (lH, d. $J=5.9 \mathrm{~Hz}, \mathrm{H}-4)$. $5.06(1 \mathrm{H} . \mathrm{d}, J=5.9 \mathrm{~Hz}$. H-5). $6.01(\mathrm{lH}, \mathrm{q}, J=7.0 \mathrm{~Hz}$. H-6). $1.59\left(3 \mathrm{H}, \mathrm{d} . J=7.0 \mathrm{~Hz}, \mathrm{H}_{3}-7\right), 7.66 .7 .73,7.84,7.85$ (each $2 \mathrm{H}$. d. $J=8.6 \mathrm{~Hz} . p-\mathrm{BrC}_{6} H_{4} \mathrm{COO} \times 2$ ).

Crystallographic data and data collection parameters. A colorless tetragonal prism of 5a was obtained by recry stallization from $n$-hexane and acetone. A single crystal with dimensions of $0.42 \times 0.22 \times 0.21 \mathrm{~mm}$ was used for X-ray diffraction data on Bruker SMART CCD diffractometer enploying graphite-monochromated Mo-K $\alpha$ radiation $(\lambda=0.71073 \AA)$ in the $\varphi-\omega)$ scan mode at $120 \mathrm{~K}$

The data were corrected for absorption $\left(T_{\mathrm{malx}}=0.92+T_{\mathrm{min}}=\right.$ $0.537)$ with SADAPS. The structure was solved by a direct 
methods of SHELXS-97, and refined by SHELXI-97 using 3151 reflections $[I>2.0 \sigma(I)]$ for 263 parameters. The final values are $\mathrm{RI}=0.0495, \mathrm{wR} 2=0.1317$, and $\mathrm{GOF}=1.016$.

Crystallographic data $\mathrm{C}_{21} \mathrm{H}_{13} \mathrm{Br}_{2} \mathrm{ClO}_{5}$, triclinic with space group P-1. with $a=6.68+7(5) \AA . b=12.1890(9) \AA, c=13.078$ (1) A. $\alpha=83.984(1)^{\circ}, \beta=80.366(1)^{\circ}, y=84.514(1)^{\circ}, V=$ $10+1.5$ (1) $\AA^{3}$. and $Z=2$. Crystallographic data for the structure reported in this paper have been deposited with Cambridge Crystallographic Data Centre (deposition number CCDC 615055). Copies of the data can be obtained. free of charge at www.ccdc.cam.ac.uk/conts/retrieving html, from the Cambridge Crystallographic Data Centre. 12 Union Road. Cambridge CB2 lEZ. UK: (Fax: +44-1223/336033: E-mail: depositacedc.cam.ac.uk).

\section{Results and Discussion}

A broth extract of $T$. viride showed antity rosinase activity. which was purified by assay-guided isolation to produce three cyclopetenone derivatives (1-3). Two cyclopentenones, my rothenones $A(1)$ and $B(2)$. were obtained in the form of colorless oils. Myrothenone A (1) is unstable at room temperature. so determination of the structure was commenced from my rothenone B (2).

The molecular formula of $\mathbf{2}$ was demonstrated to be $\mathrm{C}-\mathrm{H}_{9}$ $\mathrm{NO}_{2}$ (four unsaturations) with HRFABMS and ${ }^{13} \mathrm{C}$ NMR methods. The IR absorption spectnum of $\mathbf{2}$ shows bands characteristic of hydroxyl and amino groups $\left(3390 \mathrm{~cm}^{-1}\right)$ and enone $\left(1630 \mathrm{~cm}^{-1}\right)$ functionality. The ${ }^{1} \mathrm{H}$ and ${ }^{13} \mathrm{C}$ NMR spectra. including DEPT. showed the presence of one carbonyl, one terminal vinyl. one primary amine. one oxygenated $\mathrm{sp}^{2}$-quaternary carbon and one diastereotopic methylene group. However. the assignument of two sp ${ }^{2}$-canbons. $\dot{\delta}_{0} 95.8$ and 174.7 . was confused because both signals were observed considerably upfield and downfield, respectively, as signals of double bond. The $\alpha$-and $\beta$-carbon signals of enamine are deshielded and shielded from the resonance effect of the enamine group. respectively. ${ }^{\prime 2}$ Consideration of the resonance stnicture of enamine and the two chemical shifts. upfield and downfield. suggests the presence of an aliphatic enamine group in the molecule. The presence of a 3 -aminoenone chromophore is also supported by UV spectral data [203 $\mathrm{nm}(\log \varepsilon 3.7) .268$ $(+.0)$ ]. Detailed analysis of the spectral data. including 2D NMR data, established the full assignment of the NMR signals and the molecular structure of 2 . except for the stereochemistry at the asymmetric center.

To detemine the absolute stereochemistry of $\mathbf{2}$, an X-ray diffraction analysis of the $p$-bromobenzoyl derivative. 3-( $\mathrm{N}-\mathrm{p}$ bromobenzoyl)myrothenone B (2a), was performed. The crystal stnicture is shown in Figure 1. The bond distances and angles are all nonnal. The C-1. C-2, $\mathrm{C}-3$. and $\mathrm{C}-4$ atoms are in a plane. with a maximum deviation of $0.004 \mathrm{~A}$. and $\mathrm{C}-5$ is displaced toward a beta-orientation from the plane of the other four carbon atoms [diagonal angle : $15.1(0.5)$ ]. Therefore. cyclopentenone 2 shows a typical envelope geometry. The absolute configuration of the asymmetric center of 2 has been unambiguously determined to be $5 R$ by refinement of the Flack parameter. ${ }^{23}$

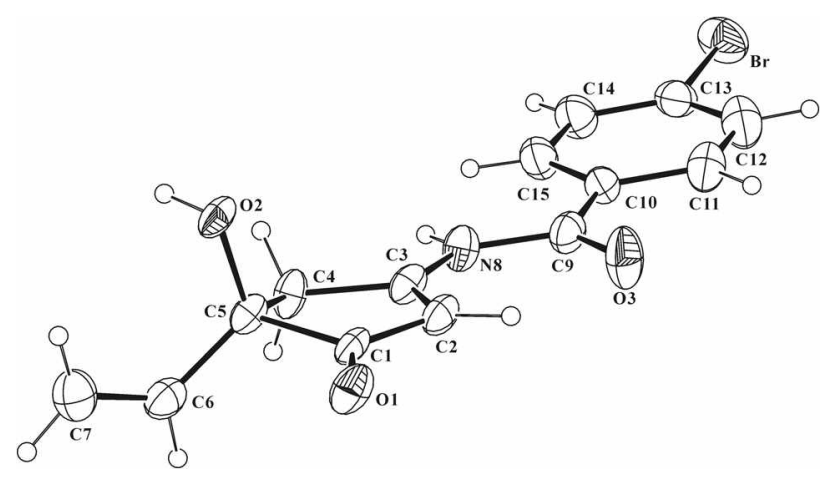

Figure 1. An ORTEP III drawing of $p$-bromobenzoate (2a). Displacement ellipsoids are drawn at $30 \%$ probability level.

Myrothenone A (1) is unstable, and the NMR signals measured at room temperature were deformed. Therefore. all the NMR signals were obtained at low temperature $\left(-50^{\circ} \mathrm{C}\right)$. The HRFABMS and ${ }^{13} \mathrm{C}$ NMR methods established that the molecular formula is $\mathrm{C}_{8} \mathrm{H}_{5} \mathrm{NO}_{3}$. The general features of its UV. IR, and NMR spectra closely resemble those of my rothenone $\mathrm{B}(2)$, except for the appearance of additional signals for one proton and one carbon $\left[\hat{\tilde{o}}_{\mathrm{H}} 8.11(\mathrm{H}-9)\right.$. $\left.\hat{\mathrm{o}}_{\mathrm{C}} \mathrm{C} 64.1(\mathrm{C}-9)\right]$ (Table 1). Detailed analyses of the ${ }^{1} \mathrm{H}$ and ${ }^{13} \mathrm{C}$ NMR spectra of 1. including the results of DEPT. HMQC. and HMBC experiments. suggest that 1 is a formamide derivative of 2.4 The key HMBC correlation from $\mathrm{H}-9$ to $\mathrm{C}-3$ was critical in establishing the location of the aldelyde group. as shown. On the basis of these data, the structure of my rothenone $A$ is proposed to be the 5-ethenyl-3-fonnamido-5-hydroxy-2-cyclopenten-Ione (1). To clarify the structure of 1 , we synthesized 1 from 2 with a fonnylation reaction using fonnic acid and 1.3 -dicyclohexylcarbodiimide as the base. ${ }^{\text {? }}$ The spectral data for the synthetic contpound were identical to those for myrothenone A (1) in all respects. Accordingly. the absolute stereostructure of my rothenone A was determined to be 5(R)-5-etheny 1-3-formamido-5-hyddroxy-2-cyclopenten-I-one (1). Vinylcyclopentenone analogues have been reported as artifacts ${ }^{25}$ and conjugated adducts, ${ }^{27}$ but natural products of this class with an amino group (1. 2) are very rare.

During a search for bioactive constituents of marine microorganisms. we isolated two cyclopentenone derivatives. bromonyrothenone $B(4)$ and botrytinone (5). from a broth extract of $R$. stolonifer. Bromomyrothenone $\mathrm{B}(\boldsymbol{t})$ is a colorless oil with isotopic cluster (a ratio of $1: 1$ ) at $m / z 217$ and 219 in its mass spectrum. suggesting the presence of a bronine atom. The molecular formula of 4 was shown to be $\mathrm{C}_{-} \mathrm{H}_{3} \mathrm{BrNO}_{2}$ (four unsaturations) by HREIMS and ${ }^{12} \mathrm{C}$ NMR methods. The $\mathbb{R}$ absorption spectnum of $\mathbf{4}$ shows bands characteristic of hydrosyl and amino groups $\left(3321 \mathrm{~cm}^{-1}\right)$ and enone $\left(1630 \mathrm{~cm}^{-1}\right)$ functionalities. The general features of the UV. IR, and NMR spectra of 4 closely resemble those of myrothenone B (2). except that the NMR signals at $\mathrm{C}-2$ are changed from the $\mathrm{sp}^{2}$-methine $[\hat{o}+70$ (s. H-2) 95.8 (C-2)] of myrothenone B (2) to an $\mathrm{sp}^{2}$-quatemary carbon $[\delta 86.1(\mathrm{C}-2)]$ in 4 . The ${ }^{1} \mathrm{H}$ and ${ }^{12} \mathrm{C}$ NMR spectra of 4 , including DEPT. show a monosubstituted double bond. a tetrasubstituted double bond. a primary anine, an oxygenated quaternary carbon. a carbonyl carbon. 
Table 1. NMR Spectroscopic Data (400 MHz, DMSO- $d_{b}$ ) for Myrothenones A (1), B (2), Bromomyrothenone B (4), and Botrytinone (5). ${ }^{a}$

\begin{tabular}{|c|c|c|c|c|c|c|c|c|}
\hline \multirow{2}{*}{$\frac{\mathrm{C}}{\text { position }}$} & \multicolumn{2}{|l|}{1} & \multicolumn{2}{|l|}{2} & \multicolumn{2}{|l|}{4} & \multicolumn{2}{|l|}{5} \\
\hline & $\partial_{\mathrm{H}}(J$ in $\mathrm{Hz})$ & $\delta \mathrm{c}$ (mult.) & $\delta_{\mathrm{H}}(J$ in $\mathrm{Hz})$ & oc (mult. ) & $\partial_{\mathrm{H}}(J \mathrm{in} \mathrm{Hz})$ & $\partial \mathrm{c}$ (mult.) & $\delta_{\mathrm{H}}(J$ in $\mathrm{Hz})$ & Sc (mult.) \\
\hline 1 & & $200.5(\mathrm{~s})$ & & $200.5(\mathrm{~s})$ & & $193.3(\mathrm{~s})$ & & $195.7(\mathrm{~s})$ \\
\hline 2 & $4.97, \mathrm{~s}$ & $98.2(\mathrm{~d})$ & $4.70, \mathrm{~s}$ & $958(\mathrm{~d})$ & & $86.1(\mathrm{~s})$ & $6.12, \mathrm{~s}$ & $124.9(\mathrm{~d})$ \\
\hline 3 & & $180.6(\mathrm{~s})$ & & $174.7(s)$ & & $169.6(\mathrm{~s})$ & & $184.2(\mathrm{~s})$ \\
\hline \multirow[t]{2}{*}{4} & $2.64, \mathrm{~d}(7.5)$ & $44.9(\mathrm{t})$ & $2.45, \mathrm{~d}(17.1)$ & $42.7(\mathrm{t})$ & $2.79, \mathrm{~d}(16.9)$ & $42.1(\mathrm{t})$ & $4.69, \mathrm{dd}(7.3,3.0)$ & $77.1(\mathrm{~d})$ \\
\hline & $2.86, \mathrm{~d}(7.5)$ & & $2.61, d(17.1)$ & & $2.56, \mathrm{~d}(16.9)$ & & & \\
\hline $4-O H$ & & & & & & & $6.36, \mathrm{~d}(7.3)$ & \\
\hline 5 & & $80.6(\mathrm{~s})$ & & $78.1(\mathrm{~s})$ & & $76.5(\mathrm{~s})$ & $4.48, \mathrm{~d}(3.0)$ & $65.0(\mathrm{~d})$ \\
\hline $5-\mathrm{OH}$ & & & $5.20, \mathrm{br}, \mathrm{s}$ & & & & & \\
\hline 6 & $5.83, \mathrm{dd}(17.1,10.6)$ & $141.5(\mathrm{~d})$ & $5.76, \mathrm{dd}(17.2,10.5)$ & $141.5(\mathrm{~d})$ & $5.79, \mathrm{dd}(17.2,10.6)$ & $140.5(\mathrm{~d})$ & $4.61, \mathrm{dq}(4.9,6.7)$ & $64.1(d)$ \\
\hline $6-\mathrm{OH}$ & & & & & & & $5.40 . \mathrm{d}(4.9)$ & \\
\hline \multirow[t]{2}{*}{7} & $5.18, \mathrm{dd}(10.6,1.3)$ & $115.1(\mathrm{t})$ & $5.00, \mathrm{dd}(10.5,1.7)$ & $112.3(t)$ & $5.27, \mathrm{dd}(17.2,1.6)$ & $113.3(t)$ & $1.30, \mathrm{~d}(6.7)$ & $21.2(\mathrm{q})$ \\
\hline & $5.41, \mathrm{dd}(17.1,1.3)$ & & $5.20, \mathrm{dd}(17.2,1.7)$ & & $5.08, \mathrm{dd}(10.6,1.6)$ & & & \\
\hline \multirow[t]{2}{*}{8} & & & 7.30, br, s & & $8.00, \mathrm{br}, \mathrm{s}$ & & & \\
\hline & & & $7.56, \mathrm{br}, \mathrm{s}$ & & $7.54, \mathrm{br}, \mathrm{s}$ & & & \\
\hline 9 & $8.11, s$ & $164.1(d)$ & & & & & & \\
\hline
\end{tabular}

"Recorded in $\mathrm{CD}_{3} \mathrm{OD}$ at $400 \mathrm{MHz}\left({ }^{1} \mathrm{H}\right)$ and $100 \mathrm{MHz}\left({ }^{13} \mathrm{C}\right)$ at $-50^{\circ} \mathrm{C}$.

and a diastereotopic methylene. The presence of a $1.2 .3 .3-$ tetrasubstituted enone chromophore is further supported by the UV spectral data $[210 \mathrm{~nm}(\log \varepsilon 3.7), 277(4.2)]$ and by the characteristic double bond carbon signals [ô 86. I (C-2) 169.6 (C-3)] located considerably upfield and downfield. " Detailed analysis of the ${ }^{1} \mathrm{H}$ and ${ }^{13} \mathrm{C}$ NMR spectra of 4 . including the results of DEPT, HMQC, and HMBC experiments, suggest that metabolite 4 is a 2-bromide derivative of myrothenone $B$ (2). The stereochemistry illustrated for 4 is based on optical rotation, which established that my rothenone $B(2)$ and 4 have an identical $R$ configuration at $\mathrm{C}-5$ from the same phase of the optical rotation $\left([\alpha]_{\mathrm{D}}^{-(1}+61\right)$. induced mainly by the substituent at C-5. to that of my rothenone B (2) $\left([\alpha]_{\mathrm{D}}^{3 / 2}+35\right){ }^{30}$ This conclusion is further supported by a comparison of the $\mathrm{CD}$ data for my rothenone $B(2)$ and 4 . The CD spectrum of 4 is similar to that of myrothenone $B$ (2) and shows a positive Cotton effect at $289 \mathrm{~nm}(\Delta \varepsilon .+2.9)$ and a negative Cotton effect at 265 (-1.4), indicating that both compounds share the same configuration at the asymmetric center. Based on the evidence described above. the stereostructure of bromomy rothenone $B$ was determined to be (5R)-3-amino-2-bromo-5-ethenyl-5hydro.xy-2-cyclopenten-1-one (4).

Botrytinone (5) is a colorless oil and a molecular formula of $\mathrm{C}: \mathrm{H}_{1} \mathrm{O}_{4}$, with three degrees of unsaturation, was established by HREIMS and ${ }^{13} \mathrm{C}$ NMR methods. The IR absorption spectnim of 5 shows bands characteristic of hydroxyl (3335 $\left.\mathrm{cm}^{-1}\right)$ and enone $\left(1716 \mathrm{~cm}^{-1}\right)$ functionalities. The ${ }^{1} \mathrm{H}$ and ${ }^{13} \mathrm{C}$ NMR spectra. including DEPT, show one methyl, three oxygenated methines, one trisubstituted double bond, and one carbonyl carbon. Detailed analyses of the ${ }^{\mathrm{j}} \mathrm{H}$ and ${ }^{\mathrm{i} 3} \mathrm{C}$ NMR spectra of 5, including the results of COSY and TOCSY experiments. suggest the presence of the functional groups 1-substituted hydroxyethyl. 1,2-disubstituted ethyleneglycol and 1.3. 3 -trisubstituted propenone, and the full assignment of the NMR signals. The presence of a 1.3.3-trisubstituted enone chromo- phore is further supported by a UV absorption band at $225 \mathrm{~nm}$ ( $\log \varepsilon 3.8$ ). The connection of the functional groups in 5 was determined on the basis of HMBC. Diagnostic HMBC correlations. from $\mathrm{H}-2$ to $\mathrm{C}-4$ and $\mathrm{C}-5$, from $\mathrm{H}-4$ to $\mathrm{C}-2$ and $\mathrm{C}-3$. from $\mathrm{H}-5$ to $\mathrm{C}-1$. from $\mathrm{H}-6$ to $\mathrm{C}-2, \mathrm{C}-3$, and $\mathrm{C}-4$, and from $\mathrm{H}_{3}-7$ to $\mathrm{C}-3$, showed the connections $\mathrm{Cl}-\mathrm{C} 5, \mathrm{C} 3-\mathrm{C} 4$, and $\mathrm{C} 3-\mathrm{C} 6$ in 5 . On the basis of all the foregoing evidence, the planar structure was easily determined to be 4,5-dihydroxy-3-(1-hydroxyethyl)-2-cyclopenten-1-one. although the stereochemistry was still not established. To assign the configuration at the asy mmetric centers. we analyzed the NOESY data in detail. However, decisive NOE correlations supporting the stereochemistry were not detected. This is because 5 has a flexible side chain with a chiral center. and displayed complex conformational behavior in the NOE experiment. However, the configurations at $\mathrm{C}-4$ and $\mathrm{C}-5$ were considered to be in trans when the coupling constant between $\mathrm{H}-4$ and $\mathrm{H}-5$ in $5\left(J_{\mathrm{H}-\mathrm{H} 5}=\right.$ $3.0 \mathrm{~Hz}$ ) was compared with those of previously reported trans stereoisomers of $(+)$-terrein $(J=2.3 \mathrm{~Hz}){ }^{1.28}(+)$-terrein diacetate $(J=2.9 \mathrm{~Hz}),{ }^{29}$ and dilydroterrein diacetate $(J=2.9$ $\mathrm{Hz}){ }^{-9}$ and the cis stereoisomers of $(+)$ - and (-)-isoterrein $(J=$ $5.7 \mathrm{~Hz})^{12}$ At the monent, the configuration at C-6 has not been assigned. To determine the configuration at $\mathrm{C}-6$ and to confirm the trans configuration at $\mathrm{C}-4$ and $\mathrm{C}-5$. a quantum chemistry calculation was performed. However because none of the values calculated were in good agreement with the experimental values, no definitive assignment of the configurations could be made. Therefore. we used an X-ray method to deternime the configurations at the asy mmetric centers. $p$-Bromobenzoylation of 5 with $p$-bromobenzoyl chloride in pyridine yielded two unusual $p$-bromobenzoate-5-cliloride derivatives, $\mathbf{5}$ a and its $\mathbf{5}$-epimer (5) $)$. The two products (5a and $\mathbf{5 b}$ ) showed coupling constants of $J_{\mathrm{H} \cdot \cdot \mathrm{H} 5}=3.0 \mathrm{~Hz}$ for $5 \mathrm{a}$ and $J_{\mathrm{H} \cdot \cdot \mathrm{H} 5}=5.9 \mathrm{~Hz}$ for 5ెb, indicating trans and cis conformations between $\mathrm{H}-4$ and $\mathrm{H}-5$, respectively. 


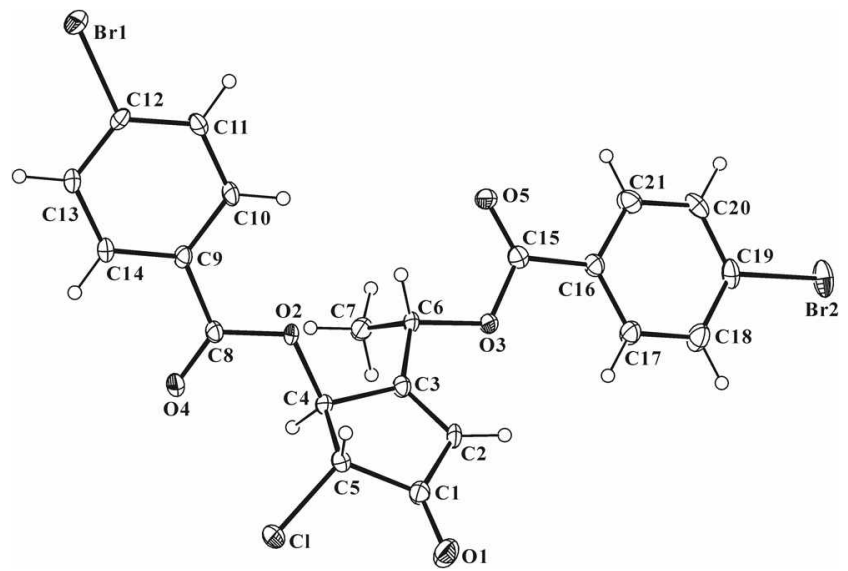

Figure 2. An ORTEP III drawing of $p$-bromobenzoate derivative (5a). Displacement ellipsoids are drawn at $30 \%$ probability level.

The stereochemistry and reaction mechanism were further supported by the $C D$ data for both products (5a. $5 \mathbf{b})$. The $C D$ spectra of $5 \mathbf{a}$ and $\mathbf{5 b}$ revealed the same negative Cotton effect at $243 \mathrm{rm}(\Delta \varepsilon .-39.9)$ and $245 \mathrm{rm}(\Delta \varepsilon .-1.07)$. indicating that both products share the same conformation at $\mathrm{C}-4$. retained during the reaction. Therefore, we infer that these two products were formed from the nucleophilic substitution of $5-\mathrm{OH}$ by a chloride ion in the $S_{\times} 1$ reaction during the benzoylation of 5 . Recrystallization of $5 \mathrm{a}$ and $\mathbf{5 b}$ from $n$-hexane-acetone only produced crystals of $5 \mathbf{a}$ The crystal stnicture of $5 \mathbf{a}$. with its relative configuration, is shown in Figure $2 .^{3(1}$ The absolute configuration of 5 was determined with the CD exciton chirality method. ${ }^{31}$ The CD spectrum of 5 a shows a negative first Cotton effect at $243 \mathrm{~nm}(\Delta \varepsilon-39.9)$. attributed to the enonebenzoate chromophores. The $\pi-\pi^{*}$ excitation of the enone group is expected to be perturbed mainly by the two allylic 4and 6-benzoate groups. The dihedral angles between enone and 4 - and 6 -benzoate are $45.3^{\circ}$ and $0.9^{\circ}$. respectively. Therefore 4-benzoate interacts mainly with the enone $\pi-\pi^{*}$ maxima to produce the first negative Cotton effect, which demonstrates the enone-t-benzoate chirality. This indicates the $4 R$ and $6 R$ configuration in $\mathbf{5 a}$ and consequently, the $4 R .5 S$. and $6 R$ configuration of botry tinone (5). On the basis of these data. the absolute stereostnicture of botrytinone was determined to be $(4 R .55,6 R)-4.5$-dilydroxy-3-(1-hydroxyethyl)-2-cyclopenten-l-one (5). The cyclopentenones isolated are small and simple molecules. Therefore. we could easily determine their molecular structures, except that of botrytinone (5). This is because botrytinone (5) has a flexible side chain with an asymmetric center. and exhibited complex conformational behavior in the NOE experiments. We tested the cyclopentenones (1-5) for radical scavenging, antimicrobial. and antityrosinase activities. and they exhibited a weak antity rosinase activity except for compound 1. Myrothenone A (1) shows potent ty rosinase inhibitory activity, with an $\mathrm{ED}_{30 \mathrm{i}}$ Falue of 6.6 $\mu \mathrm{M}$. more active than a positive standard. kojic acid ( $\mathrm{ED}_{5(\mathrm{c} .7 .7} 7.7$ $\mu \mathrm{M})$. The cyclopentenones (1-5) have already been isolated from the marine derived fungi, Myrothecium $\mathrm{sp}$. and Botrutis sp. isolated from the marine green alga Enteromorpha compressa. ${ }^{2021}$ Even though they were isolated from the different genus of the marine-derived fungus, it is likely that they all derive from common or same biogenetic internediates. presumably as part of a polyketide origin. We are now under extensive examination of cyclopentenones for better biosynthetic pathway. and the results will be reported in due course.

Acknowledgments. This research was supported in part by a grant from Marine Biotechnology Program funded by Ministry of Land. Transport and Maritime Affairs, Republic of Korea and in part by the Korea Research Foundation Grant funded by the Korean Govenument (MOEHRD. Basic Research Promotion Fund)(KRF-2008-3 14-F00048). Mass spectral data were kindly provided by the Korea Basic Science Institute. The second Brain Korea 21 graduate fellowship grant to students is gratefully acknowledged (0625-B-600285).

\section{Refelences}

1. Gutiemez, L. L. P.: Maslinkiewicz, A.; Curi, R.; de Bittencourt Ir., P. I. H. Biochem. Phamacol. 2008, 75, 2245.

2. Csaky, A. G.: Mba, M:; Plumet, J. Tetrahedron Asmmetry 2004, 15,647 .

3. Conti, M. Anti-Cancer Dngs 2006, 17, 1017

4. Pettit, G. R.: Singh, S. B.; Hamel, E.: Lin, C. M.; Alberts, D. S.; Garciá-Kendall, D. Experientia 1989, 45, 209.

5. Amagata, T.: Usami, Y; Minoura, K.; Ito, T.; Numata, A. $J$. Antibiot. $1998,51,33$.

6. Usami. Y.: Numata. A. Sulett. 1999. No. 6. 723.

7. Weidler, M.; Rether, I.; Anke, T.: Erkel, G. Biochem. Biophss. Res. Conmmin. 2000, 276, 447.

8. Lin, W; Li, L.; Fu, H.; Sattler, I.; Huang, X.; Grabley, S. $J$. Antibiot. 2005, 58,594

9. Chomcheon, P.: Sriubolmas, N.; Wiyalnuttas S.: Ngamrojanavanich, N.; Chaichit, N.: Mahidol, C.; Ruchirawat, S.; Kittakoop, P. J. Nat. Prod. 2006, 69, 1351

10. Weidler, M; Rether, T.; Anke, T; Erkel, G.; Stemer, D. J. Antibiot 2001, 54, 679.

11. Bickley, J. F.: Roberts, S. M.: Santoro, M. G.: Snape, T. I. Tetwhedron 2004, 60,2569.

12. Mikolajczyk, M.; Mikina, M.; Wieczorek, M. W.; Blaszczyk, J. Angew. Chem. Int. E. Engl. 1996, 35, 1560 .

13. Malmstrom, J.: Christophersen, C.: Barero, A. F; Oltra, J. E.; Tusticia, T.; Rosales, A. J. Nat. Prod. 2002, 65, 364

14. Lee, S.; Kim, W.-G.; Kim, E; Ryoo, I.-J.; Lee, H. K.; Kim, T. N.; Jung, S.-H.; Yoo, I.-D. Bioorg. ifed Chem Lett 2005, 15,471

15. Lubken, T.: Schmidt, T.; Porzel, A.: Anold, N.; Wessiohann, L. Phvochemismy 2004, 65, 1061.

16. Sassa, T.; Ooi, T, Kinoshita, H. Biosci. Biotechnol. Biachem. 2004, 68, 2633

17. Mitre, G. B.: Kamiya, N.: Bardon, A.: Asakawa, Y. . Nat Prod. 2004. 67.31

18. Black, W. C.; Brideau, C.; Chan, C.-C.; Charleson, S.; Chauret, N.: Claveau, D.; Ethier, D.; Gordon, R.; Greig, G.; Guav, T.; Hughes, G.; Tolicoelur, P.: Leblanc, Y; Nicoll-Griffith, D.; Ouimet, N.; Riendeau, D.; Visco, D.: Wang, Z.: Xu, L.; Prásit, P. J. Med. Chent $1999,42,1274$

19. Nam, N.-H.; Kim, Y.; You, Y.-T.; Hong, D.-H.; Kim, H.-M.; Ah», B.-Z. Bioorg. Wed. Chem. Lett. 2002, 12, 1955.

20. Li, X:; Kim, M. K.: Lee, U.: Kim, S.-K,; Kang, I. S.: Choi, H. D.: Son, B. W. Chem. Pham. Bull 2005, $53,453$.

21. Li, X; Zhang, D.; Lee, U.; Li, X.; Cheng, T.; Zhu, W; Jung, J. T.; Choi, H. D.; Son, B. W. J. Nat. Prot. 2007, 70, 307.

22. "C-MIR Spectroscopy of Organic Compounds: In Canbon-13 MIR Spectroscopv: Breitmaier, E.; Voelter, W., Eds.: VCH: Weinheim, Gemany, 1990; pp 238-240. 
23. Flack, H. D. Acta Cnstallogr. 1983, $439,876$.

24. In Structure Detemination of Organic Componds, Tables of Spectral Data; Pretsch, E.; Buhlnamn, P; Affolter, C., Eds.: Springer: Berlin, 2000; pp 140 and 224.

25. Waki, M.: Meienhofer, J. J. Org. Chem. 1977, 42, 2019.

26. Mukhopadhyay, T:; Roy, K.: Sawant, S. N.: Deshmukh, S. K.: Ganguli, B. N.: Fellhaber, H. W. J . Antibiot 1996, 49, 210.

27. Parshikov, I. A.: Moody, I. D.: Freman, I. P.: Lay, Ir., I. O.: Williams, A. J.; Heinze, T. M.; Sutherland, J. B. Mfrologia $2002,94,1$.
28. Ghisalberti, E. L.: Narbey, M. I.; Rowland, C. Y. J. Nat. Prod. $1990,53,520$.

29. Malmstrom, T.; Christophersen, C.: Barrero, A. F.; Oltra, J. E.; Iusticia, I.; Rosales, A. J. Kat. Prod 2002, 65, 364.

30. A full list of cry stallographic data and parameters is deposited at Cambridge Crystallographic Data Centre, 12 Union Road, Cambridge CB2 IEZ, UK (deposition number CCDC 615055)

31. Koreeda, M.: Harada, N.; Nakanishi, K. J. Am. Chem. Soc. 1974. 96,266 . 